\title{
The Eco Green Village Mobile Application for Waste Management
}

\author{
A.A Gde Satia Utama*, Dian Pratama \\ Accounting Department, Economics and Business Faculty, Universitas Airlangga, Surabaya, Indonesia
}

*Corresponding Author

A.A Gde Satia Utama

\section{Article History}

Received: 03.01.2021

Accepted: 15.01 .2021

Published: 20.01.2021

\begin{abstract}
One of the problems in Indonesia is cleanliness and waste management. Waste that is not correctly treated will lead to ozone pollution and become one of the factors causing climate change. This study aims at designing a system for the management of village cleanliness. This research uses qualitative methods of discovery and action study performed in Banyuwangi. Data collection is done through interviews and in-depth observation. Data analysis is done in order to produce system specifications to be created. The Eco Green Rural design, a village hygiene control device, is the outcome of this research. The contribution of this research is to allow the community to forecast the effects of climate change in terms of waste management and village cleanliness control and to encourage Smart Kampung and village movements based on technology for the government.
\end{abstract}

Keywords: Eco Green Village, Climate Change, Environmental Hygiene Knowledge System.

\section{INTRODUCTION}

The rate of waste products from Indonesia continues to rise. According to data from the Director-General for the Management of Waste, Waste and Hazardous Materials (Dirjen PSLBS), the production of waste has risen by 1 ton per day in the last two years, from 64 tons per day in 2015 to 65 tons per day in 2016. Increased production figures Obviously, this waste indicates the need to review and assess existing waste management systems and procedures.

The government is currently introducing the conventional waste management mechanism by taking existing waste out at designated waste disposal points. The trash officer will also move the trash to the final disposal site (TPA). Waste at the landfill can be processed, recycled, composted, or landfilled. Some individuals and communities have begun to conduct independent waste management and conventional waste management systems, with various new waste management technologies. Modern waste management methods are based on the paradigm of using waste for reuse or as an instrument to make money. Examples of modern waste management system advances today are waste-based power generation, waste craft production, Waste Bank, and many other technologies still in the research stage.

The waste bank is an entity active in the industry of waste management. The collection method of waste that has been separated by form for distribution to a recycling plant or a waste counter requires the waste bank's operations. One of the innovations that will help the government tackle Indonesia's waste problem is the Waste Bank Solution. Waste banks grew in quantity last year, with the positive ahead of market potential. This innovation is also compatible with Law 18 of 2008 on waste management and Government Regulation No 81 of 2012, which outlines the mandate to change the community's paradigm from the 'Gather - Transport - Dispose of' paradigm to the waste management paradigm, which has an impact on reducing the amount of waste produced.

There is also diversity in the application of waste bank business processes. Based on researchers' findings at several waste banks, there are no similar standards between waste banks. For instance, in terms of the administration of waste banks, which have different recording methods, different collecting waste methods, and no standard reference to waste bank customers for waste transactions. To access the latest waste management and management information, all links to information on savings transactions and balances can be accessed from the client-side, limited to a physical savings book or a waste bank. Other constraints are also felt for garbage banks and clients that use scheduling-based

Copyright (C) 2021 The Author(s): This is an open-access article distributed under the terms of the Creative Commons Attribution 4.0 International License (CC BY-NC 4.0) which permits unrestricted use, distribution, and reproduction in any medium for non-commercial use provided the original author and source are credited. 
garbage pickup strategies. The problem is that customers can not get information quickly on changing pickup times that can be changed. The scheduling procedure for the customer's readiness to be picked up is not flexible. In addition, several other problems in terms of efficiency caused the garbage bank sector to be sub-optimal.

The evolution of information technology is advancing so rapidly that it can enhance the productivity of businesses, such as waste banks with administrative data problems and difficulties with customer access. Internet users in Indonesia numbered 137.2 million people in 2016, according to a survey by the Indonesian Internet Service Users Association (APJII). Indonesian internet users' operation was dominated by 63.1 million people with mobile devices or smartphone users or 47.6 percent of the total Internet users. From the findings of an interview with one of the bank's waste management officers and the public, by analyzing the circumstances of the times with the rapid development of information technology, an application system is required to help the waste bank management process and the convenience of customers to access transaction data and information quickly and in real-time.

It is essential to have a general design application feature for waste bank management in order to create an application structure that can meet the needs of the waste bank sector, both in terms of waste bank management, pickup method with the scheduling system, and customer access to information, by looking at the issues and conditions of the garbage bank in Indon.

BUM Desa is a private corporation wholly or partially owned by the Village for the village community's most generous welfare by direct participation of village assets divided to manage assets, services, and other businesses. Setting up BUM Desa is to accommodate all the financial and public service activities regulated by cooperation between villages and inter-villages. The establishment of village BUMs is based on the Village Regulation regulations concerning the establishment of village BUMs and the Minister of Villages' regulations, Development of Impoverished Areas, and Indonesian Transmigration. This BUM Desa will run a website inside the administration of a garbage bank called Ecogreen Village. BUM Desa is a body that acts as the boss of a garbage bank.

The authors propose a website design called Ecogreen Village based on identifying the problem, which functions in Banyuwangi Regency to create a waste management system and control the village area's cleanliness. In addition to providing a waste management system, this website is also useful for enhancing the group's well-being by exchanging garbage collection points that are exchanged for online and e-commerce-based staples managed by BUM Desa. Based on the context of the issues mentioned, the research problem, namely how the system design focuses on the waste management approach on the Ecogreen Village website, can be inferred.

The aim and value of this research are to build a village-level waste management process design in Banyuwangi with a waste bank system through the e-commerce-based Ecogreen Village website to resolve the problem of waste to tackle the effects of global climate change.

\section{THEORY AND METHODOLOGY}

Purchasing Accounting Information System

Accounting information systems collect resources, such as people and equipment, that are structured to turn data into information. This information shall be conveyed to the various decision-making bodies [1]. The purchase concept is to procure raw materials, supporting materials, and all the business's credit or cash needs by selecting the company's best and most efficient supplier.

The company's purchasing accounting system is a system used to control the raw materials, support materials, office supplies, and fixed assets needed in the company's overall activities. The buying method helps understand the need to buy physical inventories (such as raw materials) and suppliers' orders. When items are received, the purchase mechanism tracks the occurrence by adding an inventory and generating a debit account to be paid on the date that has been set [2].

\section{Redesign of the company method}

Business Process Redesign (BPR) is an empirical analysis that re-designs business processes' fundamental aspects to minimize costs and maximize a business's added value. The renovation of a company needs to be performed carefully and thoroughly. There are two options when redesigning a business process that buys or builds a new system [3].

\section{Review of costs and benefits}

New system architecture often requires close consideration, in particular, of the costs that may be wasted in the implementation of a new system. Cost and benefit analysis can help assess whether or not the system is best implemented. Cost and benefit analysis helps managers assess if the new system's benefits would be greater than the 
costs incurred [4]. However, the assessment of costs and benefits cannot be carried out properly because it is still reviewed and preliminary estimates.

Hall [4] states that three measures can be used to perform a cost and benefit study, namely:

\section{Identification of costs}

Cost recognition can be performed in two categories: first, one-time costs or costs to make an initial investment in the production or installation of a new system; and second, ongoing costs are operating costs for the life of the system used.

\section{Identification of benefits}

Measurement of benefits gained or recognition of benefits can be seen on both sides, including tangible and intangible benefits.

\section{Costs and Benefits Comparison}

There are two widely used methods of calculating costs and benefits in the implementation or development of information systems, namely (1) the NPV process, the net present value using the present value or the current value of all costs minus the present value of the benefits to be used over the life of the system (2). The payment method is a variant of the break-even analysis. The break-even point is reached when the total costs incurred are equal to the total benefits produced.

\section{METHOD OF ANALYSIS}

Taylor 2016 states that the analysis approach identifies a problem with a ban. This research is a form of survey and exploratory analysis conducted in the Ban Yuwangi District region using the triangulation method. Qualitative approaches are used to analyze social trends and human issues in everyday life Yin, 2011.

The survey was carried out at the beginning of the research period in Banyuwangi Regency in order to find out the social conditions of the community in particular in terms of waste management and also the management of Garbage Banks and BUMDES in each village, and then to carry out action research by actively engaging in the current waste management process in order to identify weaknesses in the process. An exploratory approach means that researchers make explicit findings of the waste management system.

This study style used exploratory research with a qualitative method of approach. This method emphasizes the element of an in-depth understanding of the issue. Study subjects are subjects to be studied by researchers. The subjects of the research are those interested in waste management in rural villages in Banyuwangi Regency. This research focuses on the efficiency that occurs after applying the Ecogreen Village in the Banyuwangi Regency.

Data collection techniques are a tool used by researchers to gather data from a sample. In this study, the researcher chooses the form of qualitative research so that the data collected must be in-depth, consistent, and precise. In this study, researchers used data collection techniques to utilize a literature and documentation study. Literature analysis is a data collection method used to study reference books, papers, magazines, journals, and other media related to the research topic. Sugiyono's text [6] is a record of events that have already passed. Documents used by researchers in the form of photographs, videos, and data on village officials' activities manage existing waste.

\section{Design of analysis}

The research design of the researcher is defined as the following chart:

1. Conducting analysis

2. Collection of primary data from residents and waste bank managers through interviews and reporting.

3. Validate the collected data

4. Analyze data, draw conclusions, and develop the method.

\section{RESUlTS AND DisCUSSIONS}

Ecogreen Village is an e-commerce website designed to create a waste management and sanitation system in Banyuwangi. The party responsible for waste management is the Waste Bank management and the group through the website. The operator is BUM Desa. The waste management process begins when residents negotiate a pick-up plan that has been sorted and negotiated with the management of BUM Desa. The price of the waste deposited at BUM Desa will be entered automatically via the application and be saved for the residents. The price has been determined based on the form and amount of waste deposited. Residents can benefit from this through a waste management system built on the Ecogreen Village website. Managing traditional waste banks in which people carry their waste to the Village Waste Bank 
and get the money with manual calculations. This leads many people to litter because the purchasing price is not equal to the Garbage Bank Village costs. A pick-up that residents can organize is the right option for introducing the Garbage Bank, and the results of the deposit can be used as a balance to meet needs if a lot has been collected. All this can be achieved using the web system of Ecogreen Village. The following is the Ecogreen Village system design, which explains how the Ecogreen Village system works.

\section{Data Flow Diagram}

Data flow diagrams are representative graphs that show the flow of information that is used as input and output data [5]. The following is the DFD of the Ecogreen Village website:

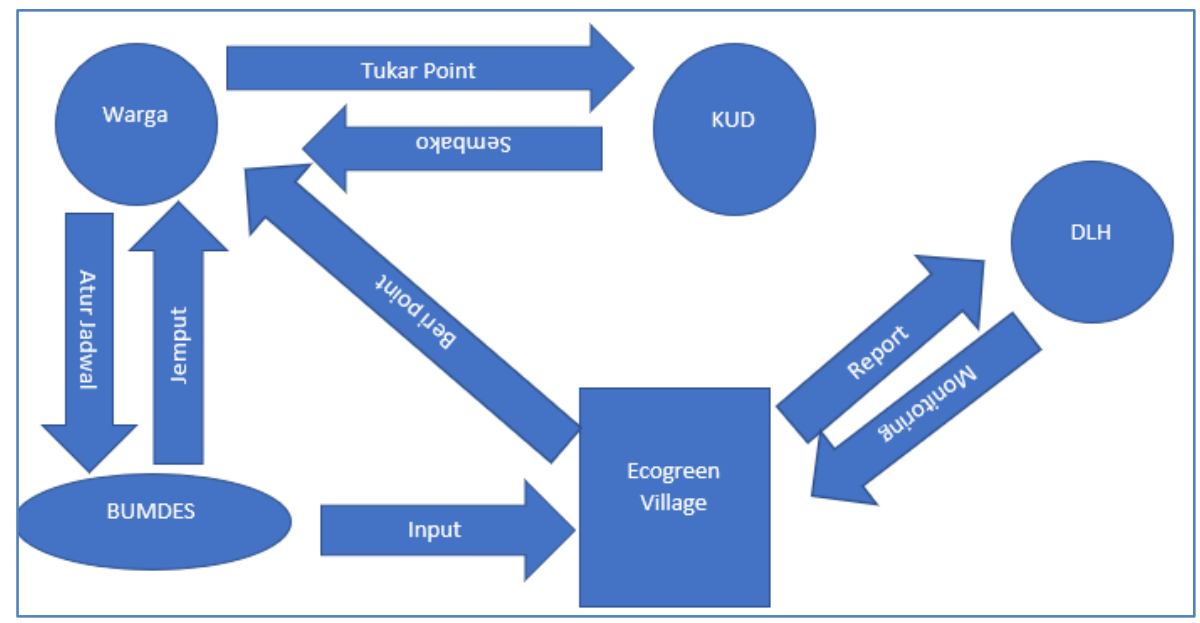

Fig-1: Diagram of data flow-Ecogreen Village

Krismiaji [7] states in his book "Accounting Information Systems" that flowcharts are analytical methods used to describe, precisely, and logically the facets of information systems. Flowcharts use a standard set of symbols to define the flow of data in the system. In this case, the authors define the General Functional Draft Management and Business Management Framework for Waste Banks systemized with the Ecogreen Village as follows:

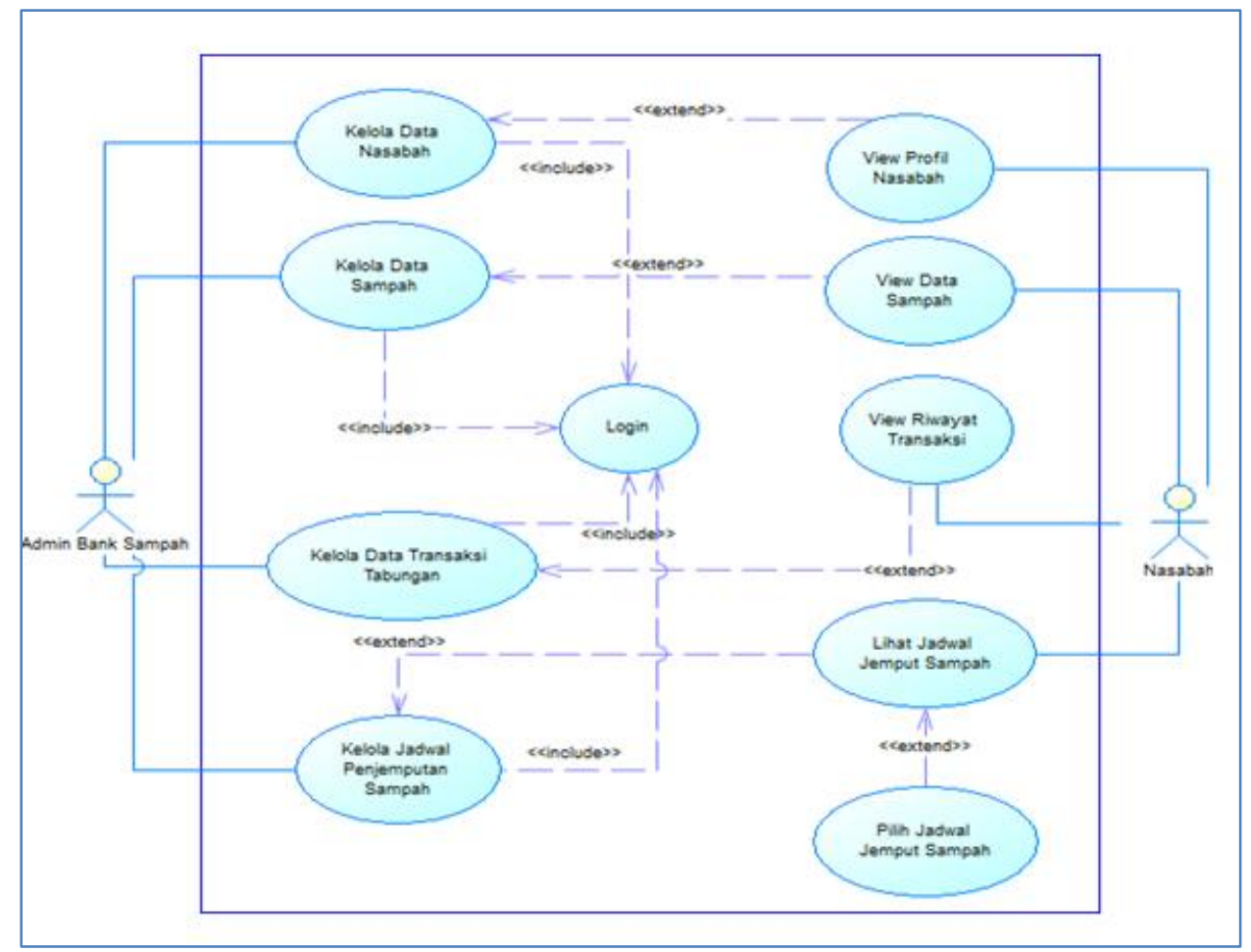

Fig-2: Flowchart - Ecogreen Village

The application feature functionality in Figure 2 includes two actors: the garbage bank administrator and the customer involved in the integrated Ecogreen Village website system. The proposed design features include managing 
customer data, managing waste data, managing savings transaction data, and managing garbage collection schedules, which are built based on two fundamental problems that occur in the garbage bank, including the method of gathering data on the management of the waste bank, as well as the accessibility of information and the scheduling of garbage collection.

In order to support the design of the application feature functionality, the application infrastructure design was planned to enable the classification of the features to be installed on the application platform in line with the needs of the waste bank business process. The architecture of the application infrastructure can be seen in Figure 3.

Design of Infrastructure Application Management for the Business and Management of Garbage Banks Application of Infrastructure Management in Figure 3. Illustrate the idea of the server-side of the client. The proposed design features some of the features required on the web, such as managing customer data, managing garbage data, managing transaction data and saving waste, and managing the garbage collection schedule.

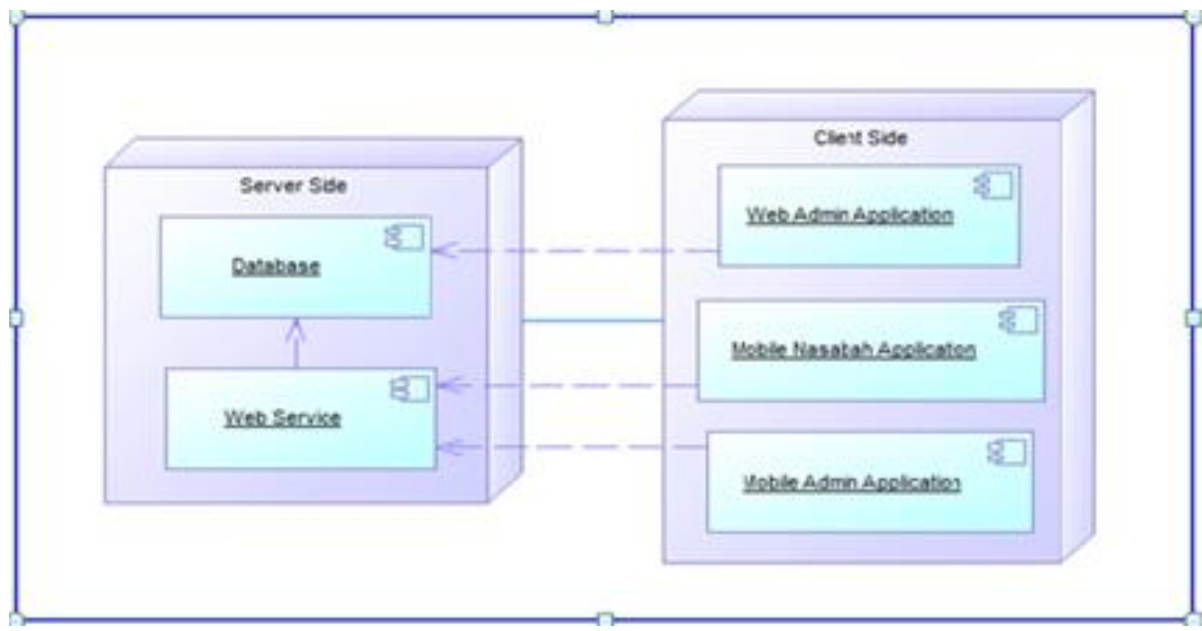

Fig-3: Concept of Infrastructure-Ecogreen Village

\section{Project Display}

The view of the log-in menu on the BUM Desa-managed Ecogreen Village website is illustrated in Figure 4. The required input data is the user name and password of BUM Desa. To manage and track the hedging and marketing system on the Ecogreen Village website, the BUM username and password are obtained from the Environment Agency by BUM Desa.

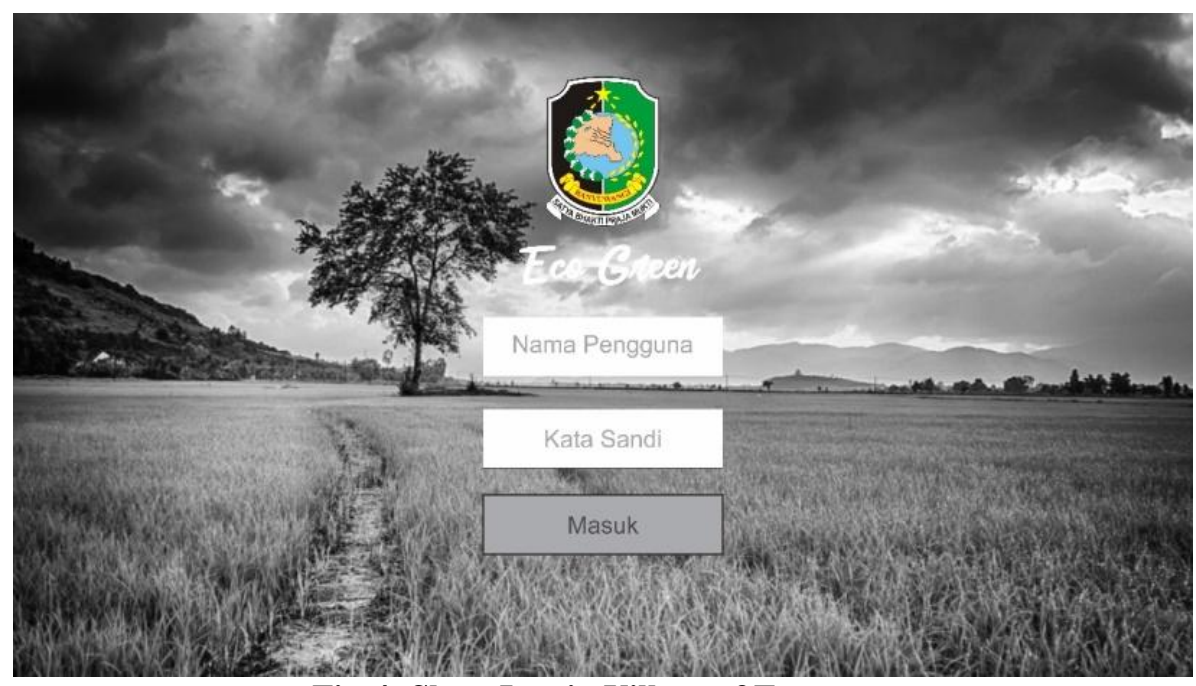

Fig-4: Show Log in Village of Ecogreen

On the Ecogreen Village website, BUM Village operators who have acquired a username and password can then access and process the waste bank business. There are four primary menus on the Ecogreen Village website dashboard: Pick Up, Check Point, Exchange Points, and Website. 


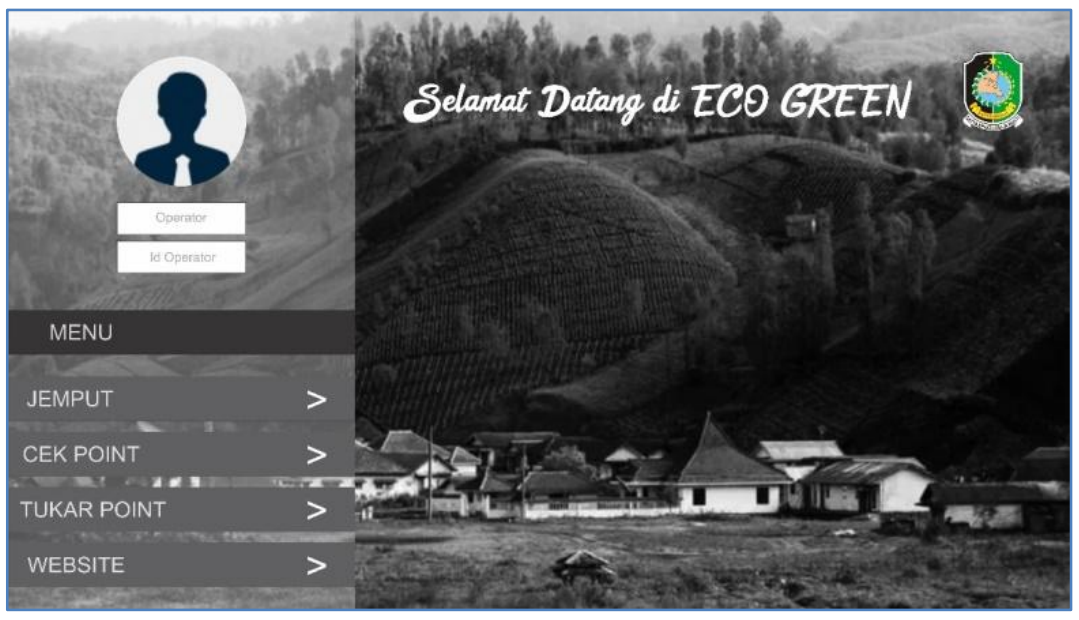

Fig-5: View Kanca Tani Log In

When customers visit the Ecogreen Village website, this page is the main page. This page has a menu on the homepage that provides information on agricultural commodities news. The "About Us" menu offers information on the vision and mission of creating the Ecogreen Village website. Information about the product being sold is displayed on the product menu. Personal accounts are a menu that registers citizens' data to follow the smart village system and Ecogreen Village. The contact number for the waste management service is our contact menu feature for complaining about customers, which is shown. The Swap Point menu is for KUD's that include basic needs that can be exchanged with savings points for people after residents have registered their data in my account.

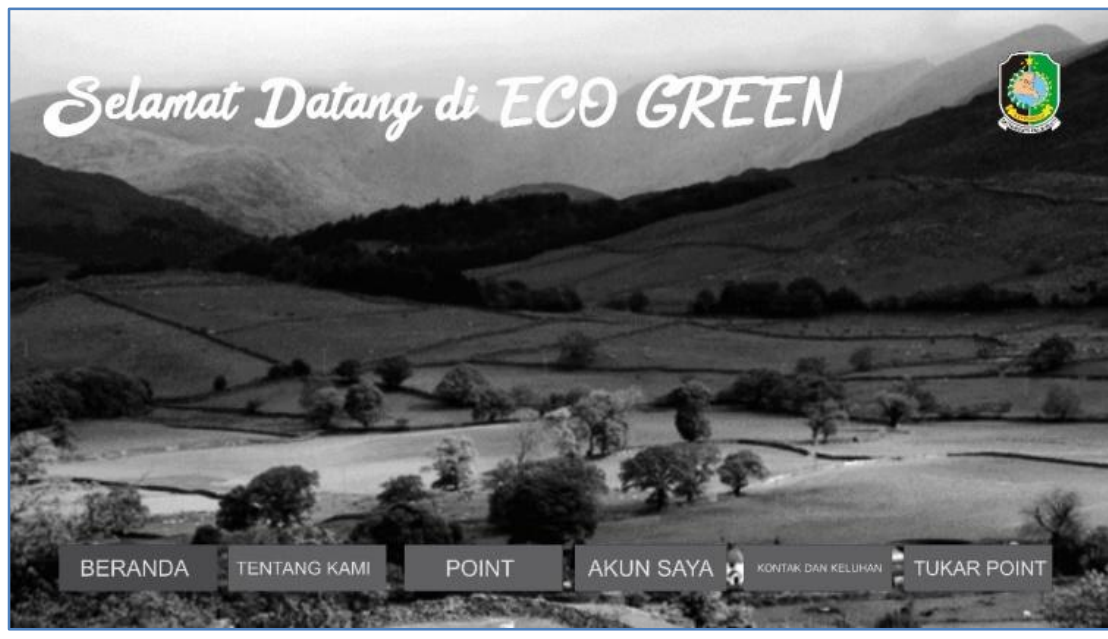

Illustration 6. Welcome Show

\section{Manage features for customer data}

This function allows the garbage bank administrator to process the collection of customer data at the garbage bank. With this feature, customers can access membership information at a registered waste bank as a customer, including verification and customer information adjustments that can be changed directly by the customer via the customer's application. The prototype specification for customer data management functionality is as follows: 


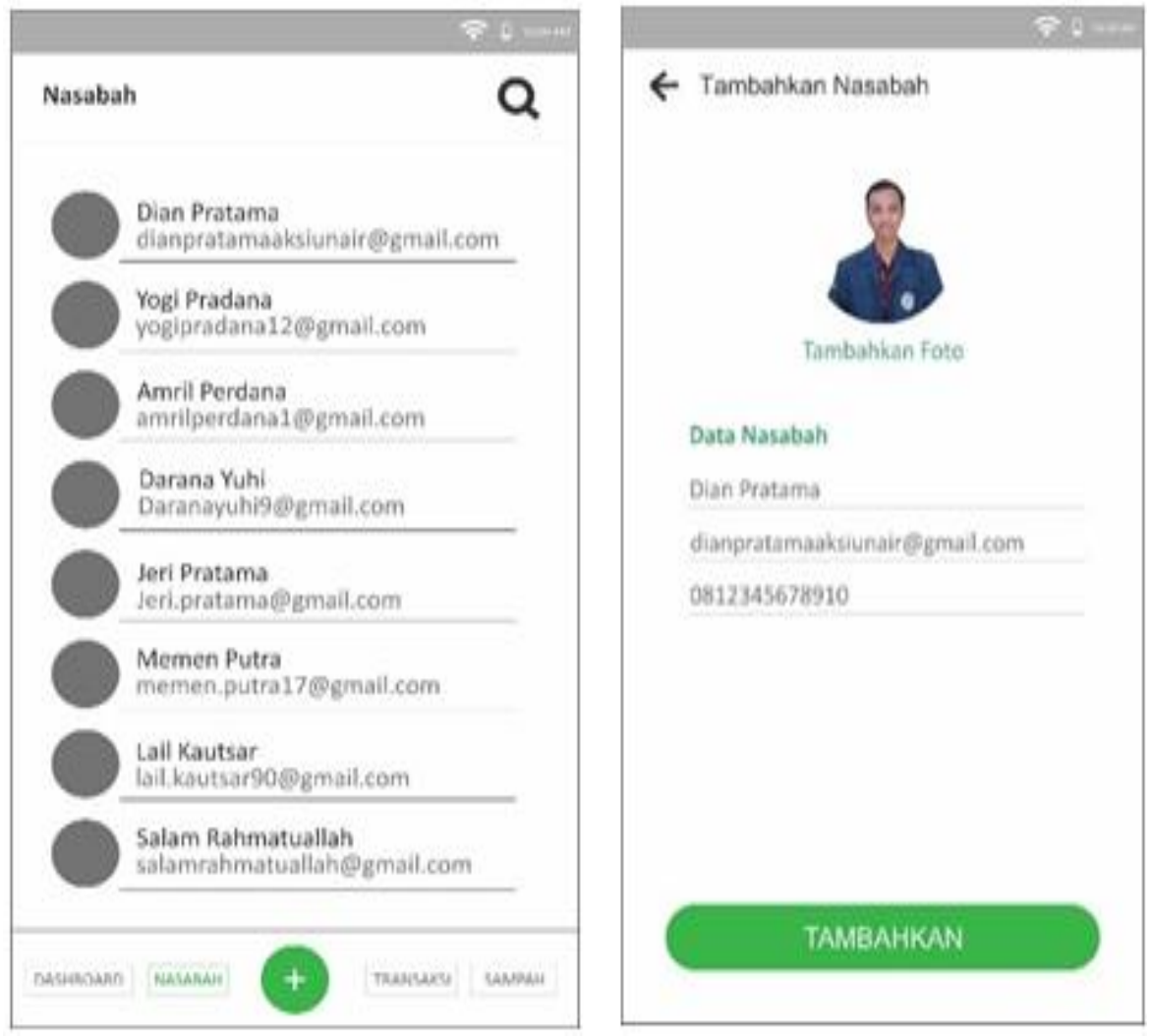

Illustration 7-8. Input Customer - Customer's database

\section{Junk Data Manage Features}

The Customer Data Management function allows the garbage bank administrator to collect data on waste available for purchase, see the total weight of waste collected, and ease the purchase prices of waste. The contrast and adjustments in the selling price of waste can be easily seen from the client or the public via the application. The prototype design for the garbage data management function is as follows:

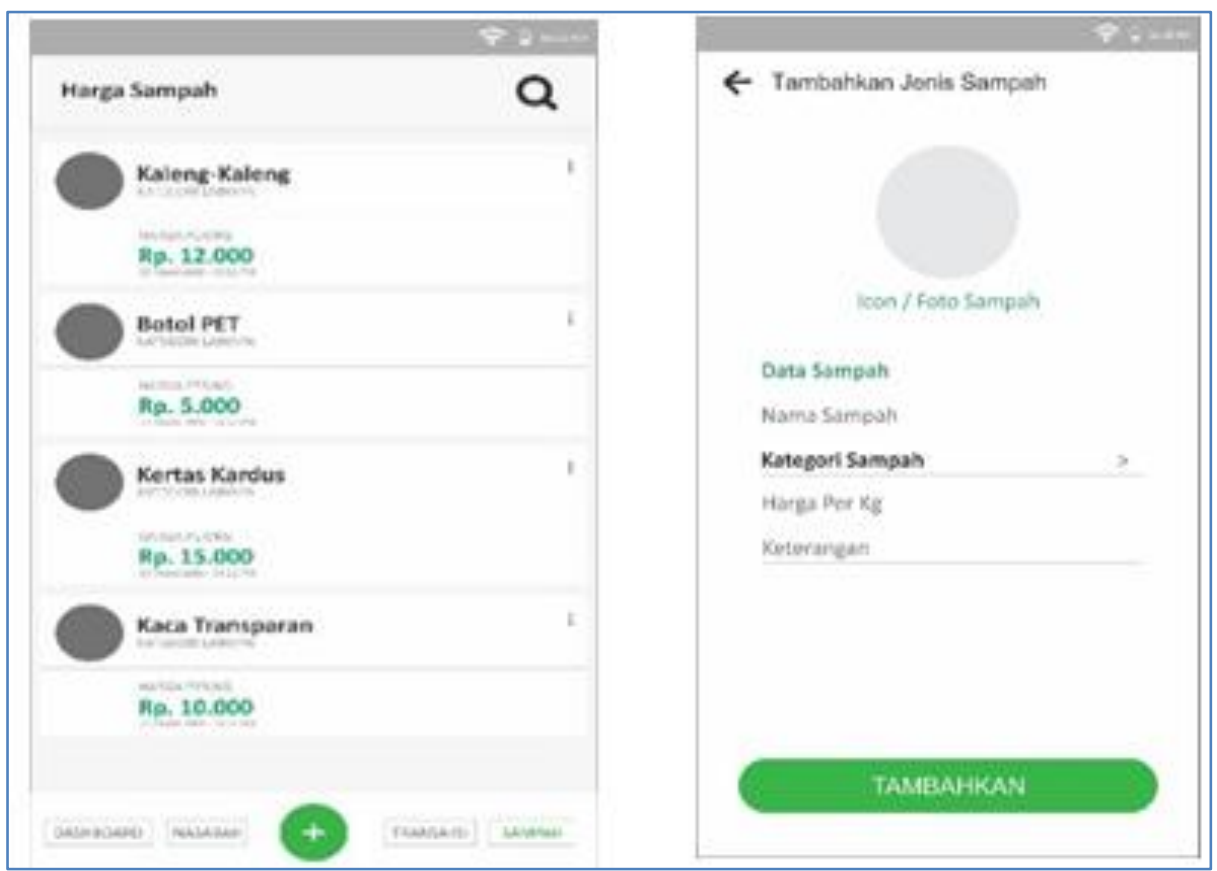

Fig-9: Input Garbage Data 


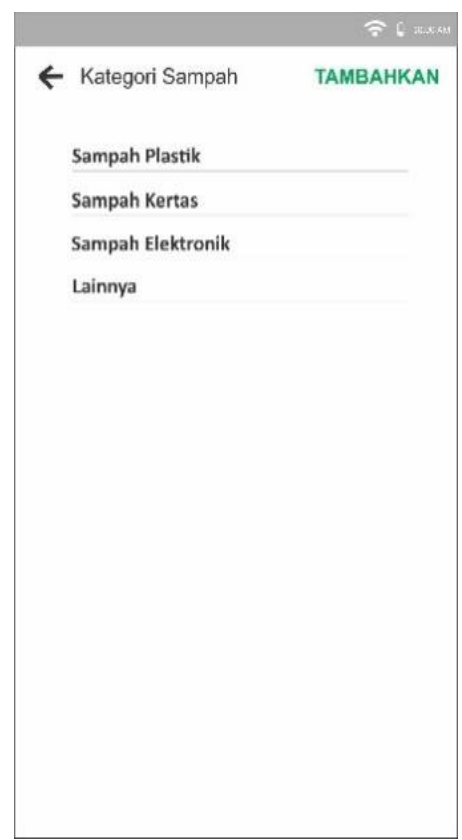

Fig-10: Group of Waste

\section{Management of Garbage Savings Transaction Data Characteristics}

Waste savings are the principal business operation in a garbage deposit. The savings mechanism itself requires garbage deposits and balances of consumer savings. The data management function of the waste savings transaction allows the administrator of the garbage bank and the client to make a direct waste deposit transaction and see all details of the transaction of the garbage deposit or withdrawal of the client's balance. From the admin application and customer application, all data can be accessed. The following is the prototype specification for the management features of transaction data for waste savings:

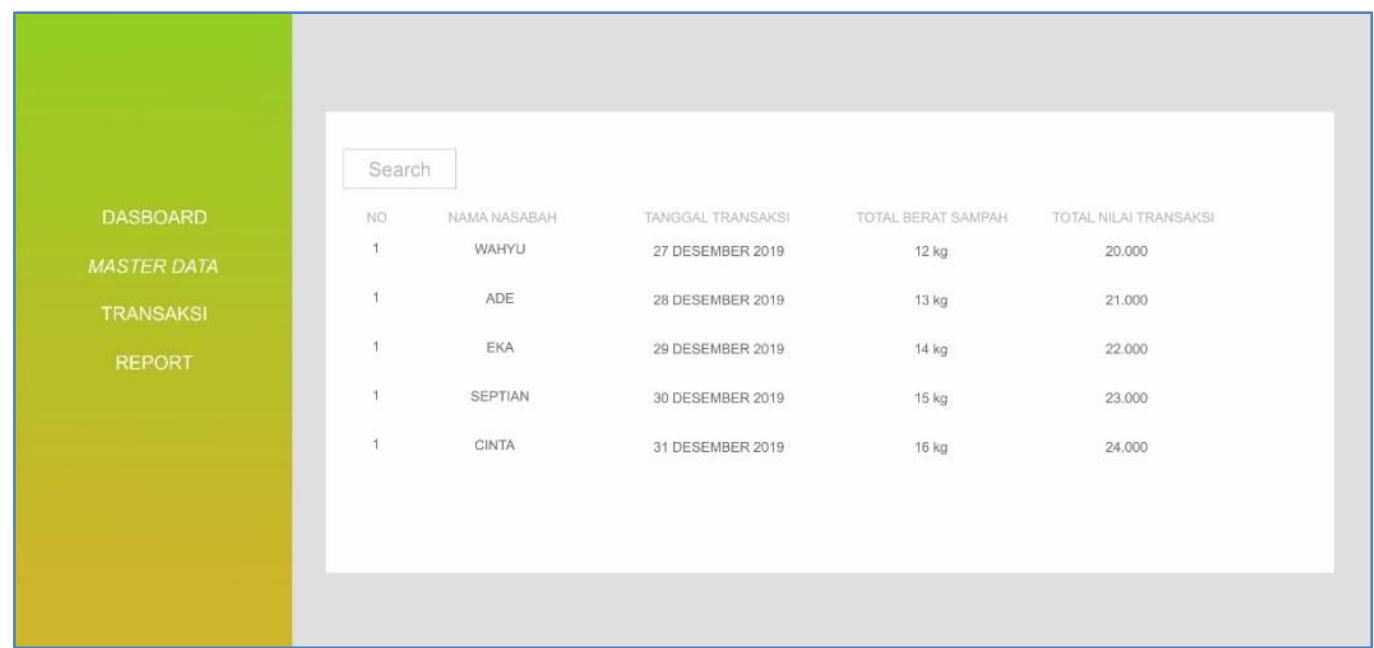

Fig-11: Characteristics of the Trash Bank Transactions List

\section{Manage Feature for Waste Pickup Schedule}

There are usually two methods of depositing waste in the waste saving process, namely the direct waste deposit system and the garbage collection method. It can be divided into two in the garbage pickup process: a garbage pickup request and a scheduled garbage pickup. The direct waste deposit method and the scheduled garbage collection method are the most commonly applied to the garbage bank among the garbage bank's many methods. Thus, as a proposed feature design, the waste scheduling management mechanism becomes a pressure point. For the waste pickup schedule management feature, here is the prototype design:

\section{Ecogreen Village is How It Works}

a. A copy of the KTP (Identity Card) is sent by every person to BUM Desa. 
b. A KTP copy is received by BUM Desa and is correct. If correct, the data will be entered on Ecogreen Village's website, and a copy will be returned to the residents if it is invalid.

c. On the Ecogreen Village website, documents that meet the requirements set out by BUM Desa are uploaded.

d. After BUM, Desa enters data on the Ecogreen Village website. The BUM Desa operator will establish a citizen account. This is useful for the process of waste management through the website of Ecogreen Village.

e. Residents will use the Ecogreen Village website once the data has been revised.

f. On the Ecogreen Village website operated by BUM Desa operators, pick-up notifications will automatically appear.

g. BUM Desa will offer points to residents via the website.

h. The collected points can be moved to the KUD with groceries that cost the collected points' equivalent.

The Ecogreen Village system concept allows the community to solve the issue of waste in the village community. Ecogreen Village's website also promotes the method of waste disposal without having to come directly to the waste bank.

This system needs high costs in terms of cost and benefit analysis, such as programmer commission fees, software design, software maintenance, farmers' socialization costs, and BUM Des labor costs to run the Ecogreen Village website. Apart from the high costs, however, the Ecogreen Village system provides enormous benefits, particularly for people and the government. Instead of using the Ecogreen Village scheme, residents can reap the advantages by having points that can be traded for groceries in village unit cooperatives (KUD).

The Ecogreen Village website adopts HTML code in its activities and uses internet technology. Several parties are involved in this scheme, namely BUM Desa, Citizens, KUD, and the Office of the Environment, which act as monitors on the Ecogreen Village website to enforce the waste management system. BUM Desa is the operator of the Ecogreen Village website that implements a system of garbage banks.

In addition to having the advantages of developing this device, risks exist in its implementation as well. They are as follows:

a. It is costly because a lot of human resources are needed.

b. It needs an extended period (required to improve the system) because it requires a direct survey and a new group culture.

c. Rollover from Superintendent of BUM Desa.

d. The running of the Ecogreen Village website is difficult for BUM Desa employees.

e. Since the framework would need to be improved from time to time, the Ecogreen Village website's socialization must be gradual and constant.

f. Every year and each time, the system needs renewal.

\section{CONCLUSION}

In this case, to recognize problems and customer needs, the waste bank is focused on research results using research methods and data collection techniques in field observations and interviews. An analysis and design process is also carried out, which results in designing a website for business management and management of waste banks in the form of the practical design of the Ecogreen Village website, the design of the website infrastructure, and the display of the website design. The design results address two general problems in waste banks' business processes, namely the administrative data mechanism and the constraints on collecting updated information from waste bank customers. With this report, it is anticipated that the design features that have been built will be a guide for website construction in waste bank management.

As for suggestions for readers who want to develop from this study, similar research can be done using the following topics:

1. Add digital education content to consumer apps as learning media for waste management and production.

2. Construction of the Internet of Things smart trash application design features incorporated with waste banks and clients.

The restriction faced during this study is that device modeling has not been adopted and is still a concept given by the Banyuwangi district's government. To benefit Ecogreen Village through the waste management system, cost and benefit analysis need to be further explored. It is anticipated that the proposed concept will become a potential guideline if the structure is adopted in Banyuwangi Regency. 


\section{ACKNOWLEDGMENTS}

I thank all of Airlangga University's Accounting Bachelor Student 2017, particularly the Management Information System Class member, for comments that significantly improved the manuscript.

\section{REFERENCES}

1. Bank Indonesia. (2013). Gerai Info Bank Indonesia: Lindung Nilai Jaminan dan Pendalaman Pasar. Edisi 43. Jakarta: Humas Bank Indonesia.

2. McLeod, Jr., Raymond., \& George, P. Schell. (2007). Management Information System. Tenth Edition. New Jersey: Pearson Education, Inc

3. Suara Jatim Post [internet]. 2017. Jember: Suara Jatim Post. [Cited in 2019 March 24]. Available from http://m.suarajatimpost.com/read/10937/20171206/172653/ha rga-buah- naga-di-pasaran-tinggi-di-petanibanyuwangi-anjlok/.

4. Hall, S., Critcher, C., Jefferson, T., Clarke, J., \& Roberts, B. (2013). Policing the crisis: Mugging, the state and law and order. Macmillan International Higher Education.

5. Sukamto, R.A., Shalahudin, M. (2014). Rekayasa Perangkat Lunak Terstruktur Dan Berorientasi Objek. Bandung: Informatika Bandung.

6. Halim, Abdul, dkk. (2009). Sistem Pengendalian Manajemen. Edisi Revisi. Yogyakarta: Sekolah Tinggi Ilmu Manajemen YKPN

7. Krismiaji. (2010). Sistem Informasi Akuntansi. Yogyakarta: UPP AMP YKPN.

CITATION: A.A Gde Satia Utama \& Dian Pratama (2021). The Eco Green Village Mobile Application for Waste Management. South Asian Res J Eng Tech, 3(1): 13-22. 